

\title{
GAYA KEPEMIMPINAN \\ TRANSFORMASIONAL DAN MOTIVASI KERJA
}

\author{
Darmadi, S.E.,M.M \\ Ratna Sari S.E.,M.M
}

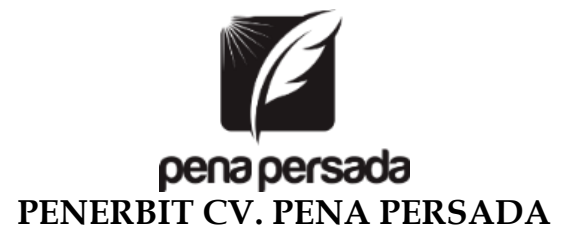




\title{
GAYA KEPEMIMPINAN TRANSFORMASIONAL DAN MOTIVASI KERJA
}

\author{
Penulis: \\ Darmadi, S.E.,M.M \\ Ratna Sari S.E.,M.M \\ ISBN : 978-623-315-262-4 \\ Editor: \\ Wiwit Kurniawan, M.A \\ Design Cover : \\ Retnani Nur Briliant \\ Layout : \\ Hasnah Aulia \\ Penerbit CV. Pena Persada \\ Redaksi : \\ Jawa Tengah \\ Email : penerbit.penapersada@gmail.com \\ Anggota IKAPI \\ All right reserved \\ Cetakan pertama : 2021
}

Jl. Gerilya No. 292 Purwokerto Selatan, Kab. Banyumas

Website : penapersada.com Phone : (0281) 7771388

Hak Cipta dilindungi oleh undang-undang. Dilarang memperbanyak karya tulis ini dalam bentuk apapun tanpa izin penerbit 


\section{KATA PENGANTAR}

Puji syukur saya panjatkan kepada Tuhan Yang Maha Esa, karena atas berkat dan rahmat-Nya, saya dapat menyelesaikan buku ini. Penulisan buku merupakan buah karya dari pemikiran penulis yang diberi judul "Efektifitas Gaya Kepemimpinan Transformasional Dan Motivasi Kerja". Saya menyadari bahwa tanpa bantuan dan bimbingan dari berbagai pihak sangatlah sulit bagi saya untuk menyelesaikan karya ini. Oleh karena itu, saya mengucapkan banyak terima kasih pada semua pihak yang telah membantu penyusunan buku ini. Sehingga buku ini bisa hadir di hadapan pembaca.

Penulis menyadari bahwa buku ini masih jauh dari kesempurnaan. Oleh karena itu kritik dan saran yang membangun sangat dibutuhkan guna penyempurnaan buku ini. Akhir kata saya berharap Tuhan Yang Maha Esa berkenan membalas segala kebaikan semua pihak yang telah membantu. Semoga buku ini akan membawa manfaat bagi pengembangan ilmu pengetahuan. 


\section{DAFTAR ISI}

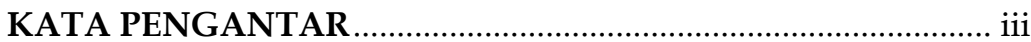

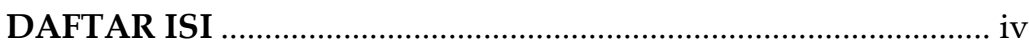

BAB I PENDAHULUAN: PENGELOLAAN SUMBER DAYA MANUSIA

A. Potensi Sumber Daya Manusia ............................................... 1

B. Faktor Pendorong Kinerja Karyawan ..................................... 2

BAB II MANAJEMEN SUMBER DAYA MANUSIA

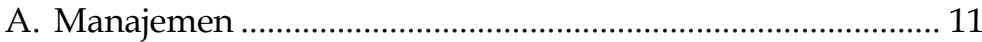

1. Pengertian Manajemen....................................................... 11

2. Fungsi Manajemen.......................................................... 12

3. Prinsip-Prinsip Manajemen ............................................... 13

4. Ciri-Ciri Manajemen ............................................................ 14

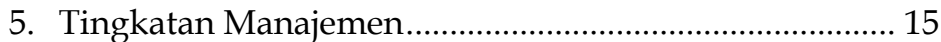

B. Manajemen Sumber Daya Manusia ......................................... 23

\section{BAB III GAYA KEPEMIMPINAN TRANFORMASIONAL}

A. Kepemimpinan Transformasional ........................................... 41

B. Latar Belakang Sejarah Kepemimpinan

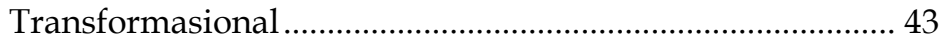

C. Definisi Kepemimpinan Tranformasional .............................. 46

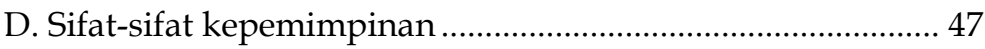

E. Fungsi-fungsi Kepemimpinan ............................................... 49

F. Karakter Kepemimpinan Transformasional .......................... 50

G. Konsep Kepemimpinan Transformasional ........................... 50

H. Indikator Kepemimpinan Transformasional ....................... 52

BAB IV MOTIVASI KERJA
A. Pengertian Motivasi 45
B. Teori - Teori Motivasi ............................................................. 46
C. Model-Model Motivasi ............................................................. 48

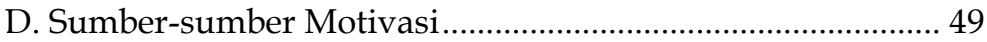

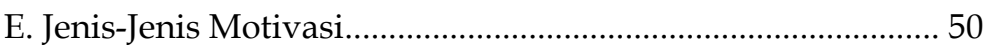
F. Indikator Motivasi Kerja ………………………........................ 51

BAB V KINERJA PEGAWAI

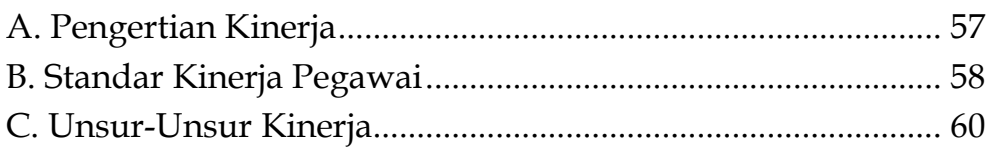




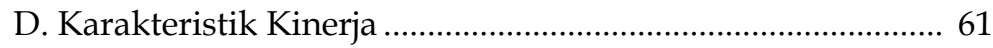

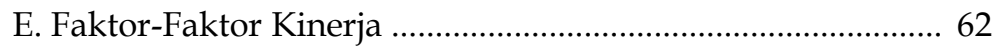

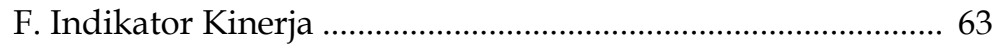

\section{BAB VI KEPEMIMPINAN TRANSFORMASIONAL DAN} KARYAWAN

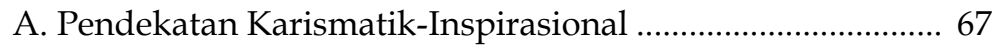

B. Dinamika Karisma Dan Krisis ................................................ 70

C. Kepemimpinan Transformasional Otentik dan

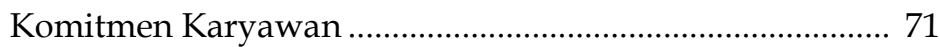

D. Kepemimpinan Transformasional dan Kinerja

Karyawan

BAB V KINERJA PEGAWAI

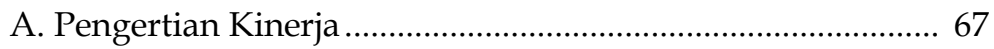

B. Standar Kinerja Pegawai ...................................................... 70

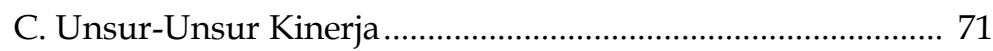

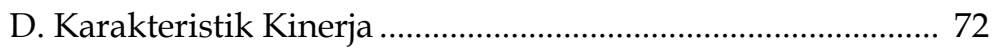

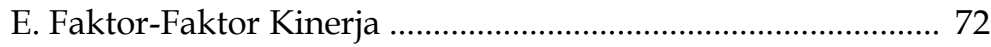

F. Indikator Kinerja ................................................................... 73

BAB VI KEPEMIMPINAN TRANSFORMASIONAL DAN KARYAWAN

A. Pendekatan Karismatik-Inspirasional .................................... 79

B. Dinamika Karisma Dan Krisis ............................................. 82

C. Kepemimpinan Transformasional Otentik dan Komitmen

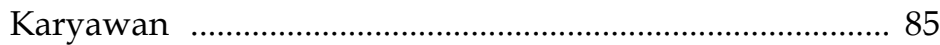

D. Kepemimpinan Transformasional dan Kinerja Karyawan 89

BAB VII PENUITUP: TANTANGAN MASA DEPAN UNTUK KEPEMIMPINAN TRANSFORMASIONAL

A. Kepemimpinan Transformasional Otentik ........................ 99

B. Pelatihan Kepemimpinan Transformasional ...................... 101

C. Gambaran Lebih Luas ........................................................ 102

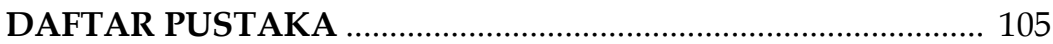



GAYA KEPEMIMPINAN

TRANSFORMASIONAL DAN MOTIVASI KERJA 



\section{BAB I \\ PENDAHULUAN: PENGELOLAAN \\ SUMBER DAYA MANUSIA}

\section{A. Potensi Sumber Daya Manusia}

Dalam era globalisasi saat ini, segala aspek kehidupan dituntut untuk bersaing menunjukan yang terbaik, karena yang terbaiklah yang akan dipilih, untuk dapat bersaing dalam pasar. Sebuah perusahaan seharusnya mempersiapkan diri menghadapi tantangan yang ada, dan sejatinya manusia yang memegang peran besar dalam sebuah organisasi atau perusahaan. Untuk melakukan perubahan ke arah yang positif, maka dibutuhkan manusia- manusia handal dalam kepentingannya manusia harus ditata dalam sebuah manajemen yaitu Manajemen Sumber Daya Manusia (MSDM).

Persaingan antar perusahaan di era globalisasi semakin tajam, sehingga sumber daya manusia dituntut untuk terus-menerus mampu mengembangkan diri secara proaktif. SDM harus menjadi manusia-manusia pembelajar, yaitu pribadi-pribadi yang mau belajar dan bekerja keras dengan penuh semangat, sehingga potensi insaninya berkembang maksimal.

Dalam suatu sistem operasi perusahaan, potensi Sumber Daya Manusia pada hakekatnya merupakan 
salah satu modal dan memegang suatu peran yang paling penting dalam mencapai tujuan perusahaan. Oleh karena itu perusahaan perlu mengelola Sumber Daya Manusia sebaik mungkin. Sebab kunci sukses suatu perusahaan bukan hanya pada keunggulan teknologi dan tersedianya dana saja. Tapi faktor manusia merupakan faktor yang terpenting pula.

\section{B. Faktor Pendorong Kinerja Karyawan}

Karyawan suatu perusahaan akan dapat bekerja dengan baik dalam menghasilkan suatu barang apabila mereka mempunyai minat dan semangat terhadap pekerjaan tersebut. Minat dan semangat tersebut dapat tumbuh apabila para pengusaha selalu menyadari akan kewajiban-kewajibannya terhadap para karyawan tersebut. Dalam hal ini membimbing, membina dan merawatnya secara wajar sesuai dengan asas-asas kemanusiaan serta menghargainya sebagai pelaksana dari perusahaan. Karyawan yang memiliki semangat kerja yang tinggi akan meningkatkan kehidupan organisasi atau perusahaan. Loyalitas dan semangat kerja dapat dilihat dari mereka merasa senang dengan pekerjaannya. Mereka akan memberikan lebih banyak perhatian, imajinasi dan keterampilan dalam pekerjaannya.

Seperti diketahui dalam organisasi terdapat salah satu unsur yaitu; manusia yang merupakan sumber daya penggerak tujuan suatu organisasi dan paling banyak berperan untuk menentukan berhasil atau tidaknya tujuan perusahaan tersebut. Sumber daya manusia atau disebut karyawan berperan dalam perencanaan, 
pelaksanaan, pengawasan, dan pengendalian organisasi agar perusahaan mencapat misi dengan baik.

Kepemimpinan merupakan faktor penting dari perusahaan sebab dalam kenyataannya pemimpin dapat mempengaruhi moral dan kepuasan kerja karyawan, keamanan, kualitas kehidupan kerja, dan terutama tingkat prestasi suatu organisasi.

Untuk mengelola dan mengendalikan berbagai fungsi subsistem dalam organisasi agar tetap konsisten dengan tujuan organisasi dibutuhkan seorang pemimpin karena pemimpin merupakan bagian penting dalam peningkatan kinerja para pekerja. Disamping itu kemampuan pemimpin dalam menggerakan dan memberdayakan karyawannya akan berpengaruh terhadap kinerja karyawan. Perubahan lingkungan dan tehnologi yang cepat meningkatkan kompleksitas tantangan yang dihadapi oleh organisasi, hal ini memunculkan kebutuhan organisasi terhadap pemimpin yang dapat mengarahkan dan mengembangkan usahausaha bawahan dengan kekuasaan yang dimiliki untuk mencapai tujuan organisasi dalam membangun organisasi menuju.

Perilaku pemimpin mempunyai dampak signifikan terhadap sikap, perilaku, dan kinerja pegawai. Efektivitas pemimpin dipengaruhi oleh karakteristik bawahannya dan terkait dengan proses komunikasi yang terjadi antara pemimpin dan bawahan. Ketidak berhasilan pemimpin dikarenakan pemimpin tidak mampu menggerakan dan memuaskan karyawan pada suatu pekerjaan dan lingkungan tertentu. Tugas pimpinan adalah mendorong 
bawahan supaya memiliki kompetensi dan kesempatan berkembang dalam mengantisipasi setiap tantangan dan peluang dalam bekerja.

Peran kepemimpinan transformasional dianggap paling cocok dari sekian banyak model kepemimpinan yang ada. Konsep kepemimpinan transformasional pertama kali dikemukakan oleh James, W (2010 ), dan selanjutnya dikembangkan oleh Bernard Bass dan para pakar perilaku organisasi lainnya.

Menurut Bass dalam Khoirus Madi (2011:7) mendefinisikan kepemimpinan transformasional sebagai kemampuan yang dimiliki seorang pemimpin untuk mempengaruhi anak buahnya, sehingga mereka akan percaya, meneladani, dan menghormatinya. Lebih lanjut Bass dalam Khoirus Madi (2011:8) mengistilahkan kepemimpinan transformasional sebagai "Fours I's", yang meliputi "pengaruh individual (individualized influence), motivasi inspiratif (inspirational motivation), stimulasi intelektual (intellectual stimulation), dan pertimbangan individual (individualized consideration)".

Motivasi atau dorongan untuk bekerja sangat penting dalam penentuan tinggi rendahnya kerja perusahaan. Sukses tidaknya suatu perusahaan, sangat tergantung dari aktivitas dan kreativitas karyawan. Motivasi juga akan mendorong seseorang untuk bekerja lebih baik agar meraih kinerja yang diharapkan, sehingga mendapatkan apa yang menjadi kebutuhannya. Oleh karena itu, motivasi sangat penting dimiliki oleh pimpinan dan karyawan dalam meningkatkan semangat kerja dan kinerja para karyawan. 
Menurut Hasibuan (2012:218) mengemukakan motifasi adalah suatu pendorong dari dalam untuk beraktivitas atau bergerak dan secara langsung atau mengarah kepada sasaran akhir.

Kinerja karyawan yang merupakan hasil olah pikir dan tenaga dari seorang karyawan terhadap pekerjaan yang dilakukannya, dapat berujud, dilihat, dihitung jumlahnya, akan tetapi dalam banyak hal hasil olah pikiran dan tenaga tidak dapat dihitung dan dilihat, seperti ide-ide pemecahan suatu persoalan, inovasi baru suatu produk barang atau jasa, bisa juga merupakan penemuan atas prosedur kerja yang lebih efisien.

Menurut Mangkunegara (2012:69) “penilaian kinerja merupakan evaluasi yang sistematis dari pekerjaan pegawai dan potensi yang dapat dikembangkan". Jadi pada dasarnya apabila perusahaan ingin meraih kinerja yang optimal sesuai dengan target yang telah di tentukan maka perusahaan haruslah memberikan motivasi pada karyawan, agar karyawan mau dan rela mencurahkan tenaga dan pikiran yang dimiliki demi pekerjaan. Persoalan dalam memotivasi karyawan tidak mudah karena dalam diri karyawan terdapat keinginan, kebutuhan dan harapan yang berbeda antara satu karyawan dengan karyawan lain. Jadi apabila manajemen dapat memahami persoalan motivasi dan mengatasinya maka perusahaan akan mendapatkan kinerja karyawan yang optimal sesuai dengan standar yang di tentukan.

Menerapkan gaya kepemimpinan yang sesuai dengan tingkat kematangan pegawai yang menjadi 
bawahaannya agar motivasi dapat di tingkatkan. Pemimpin dalam menerapkan kebijakan mesti pula memperhatiakan secara khusus aspek motivasi yang menjadi landasan untuk membuat karyawan untuk menjalankannya. Salah satu stretegi tersebut adalah dengan meningkatkan kinerja pegawainya, dengan mempertahankan kinerja pegawai tetap tinggi, maka kemungkinan besar maka karyawannya mampu bertahan dan berkembang.

Pemimpin merupakan unsur yang sangan mentukan lancar atau tidak nya suatu karyawan dalam mewujudkan tujuannya, kepemiminan merupakan inti dan motor untuk penggerak dari terwujudkannya proses oprasional yang baik. Demikian petingginya keperanan kepemimpinan dalam proses pencapain tujuan, sehingga dapat dikatakan bahwa sukses dan tidaknya oprasional sebagian besar ditentukan oleh kualitas kepemimpinan yang dimiliki orang-orang yang diserahi tugas dalam mempipin oprasional itu. Sumber daya tersebut termasuk karyawan yang bekerja disuatu perusahaan. Kepemimpinan tranformasional menjadi barometer dalam perusahaan dan turun berperan penting dalam meningkatkan kinerja karyawan.

Menurut Yukl, Gary A $(2009 ; 224)$ menyatakan bahwa kepemimpinan tranformasional sebagai pemimpin yang mempunyai kekuatan untuk mem pengaruhi bawahan dengan cara tertentu. Menurut Bass dalam Mutamimah (2012:3) mendefinisikan "kepemimpinan transformasional terjadi jika pemimpin memperluas dan membangkitkan minat karyawannya, membangkitkan kesadaran dan penerimaan tujuan dan misi kelompok". 
Dengan

penerapan

kepemimpinan

transformasional bawahan akan merasa dipercaya, dihargai, loyal dan respek kepada pimpinannya. Pada akhirnya bawahan akan termotivasi untuk melakukan lebih dari yang diharapkan.

Dalam mencapai tujuannya, organisasi harus mampu mengatur seluruh sumber daya yang terdapat didalam nya. Salah satu sumber daya organisasi atau karyawan yang membutuhan perhatian dan penaganan khusus adalah sumber daya manusia. Semuah organisasi harus mengatur dan memfasilitasi pegawainya dengan baik untuk menunjang kinerja dan menciptakan akuntabilitas publik dalam menujun good governance.

Keberhasilan suatu organisasi dipengaruhi oleh kinerja individu pegawainya, suatu organisasi akan berupaya untuk meningkatkan kinerja pegawainya dengan harapan tujuan perusahaan dapat tercapai. Kinerja pada dasarnya adalah apa yang dilakukan atau tidak dilakukan karyawan. Kinerja karyawan adalah yang mempengaruhi seberapa banyak mereka member kontribusi kepada organisasi antara lain termasuk kuantitas output, kualitas output, jangka waktu output, kehadiran di tempat kerja dan sikap kooperatif.

Kinerja adalah hasil atau tingkat keberhasilan seseorang secara keseluruhan selama periode tertentu dalam melaksanakan tugas dibandingkan dengan berbagai kemungkinan standar hasil kerja, target atau sasaran atau kriteria yang ditentukan terlebih dahulu dan telah disepakati bersama (Rivai, 2013:128). Kinerja menurut Mangkunegara (2012:87) adalah hasil kerja 
secara kualitas dan kuantitas yang tercapai oleh seseorang pegawai dalam melaksanakan tugasnya sesuai tanggung jawab yang diberikan kepadanya. Wirawan (2012 : 5 ), menjelaskan bahwa kinerja adalah keluaran yang dihasilkan oleh fungsifungsi atau indikatorindikator suatu pekerjaan atau suatu profesi dalam waktu tertentu. Dengan demikian, kinerja merupakan hal yang penting bagi organisasi atau perusahaan serta dari pihak pegawai itu sendiri. Oleh karena itu, kinerja pegawai akan berjalan dengan efektif apabila didukung dengan motivasi dan disiplin kerja.

Setiap kegiatan yang dilakukan oleh seseorang didorong oleh suatu kekuasaan dalam diri orang tersebut, kekuatan pendorong inilah yang disebut motivasi. Motivasi kerja karyawan dalam suatu organisasi dapat dianggap sederhana dan dapat pula menjadi masalah yang kompleks, karena pada dasarnya manusia mudah untuk dimotivasi dengan memberikan apa yang menjadi keinginannya. Masalah motivasi kerja dapat menjadi sulit dalam menentukan imbalan dimana apa yang dianggap penting bagi seseorang karena sesuatu yang penting bagi seseorang belum tentu penting bagi orang lain. Bila seseorang termotivasi, ia akan berusaha berbuat sekuat tenaga untuk mewujudkan apa yang diinginkannya. Namun belum tentu upaya yang keras itu akan menghasilkan produktivitas yang diharapkan, apabila tidak disalurkan dalam arah yang dikehendaki organisasi. Unsur kebutuhan berarti suatu keadaan internal yang menyebabkan hasil-hasil tertentu tampak menarik. Suatu kebutuhan yang tidak terpuaskan akan menciptakan tegangan yang merangsang dorongan-dorongan di dalam diri individu. Dorongan ini menimbulkan suatu perilaku 
pencarian untuk menemukan tujuan-tujuan tertentu yang apabila tercapai akan memenuhi kebutuhan itu dan mendorong ke pengurangan tegangan.

Menurut Mathis (2012:56) "motivasi merupakan hasrat didalam diri seseorang yang menyebabkan orang itu melakukan tindakan". Tindakan inilah yang membuat bawahan merasa memiliki tanggung jawab dan merasa dirinya dilibatkan didalam organisasi atau perusahaan. Motivasi yang muncul disini diperoleh dari adanya rasa didalam setiap individu bawahan atau karyawan akan tanggung jawab yang dia emban, untuk dijalankan dengan sebaik mungkin.

Untuk menciptakan kinerja karyawan agar berjalan dengan efektif, hal tersebut tidak hanya didorong dengan adanya motivasi saja tetapi dengan mempunyai disiplin kerja yang tinggi. Disiplin adalah prosedur yang mengoreksi atau menghukum bawahan karena melanggar peraturan atau prosedur. Disiplin merupakan bentuk pengendalian diri pegawai dan pelaksanaan yang teratur dan menunjukan tingkat kesungguhan tim kerja didalam sebuah organisasi (Ambar, Teguh Sulistiyani dan Rosidah, (2011:72). Nitisemito (2009:178) mengemukakan disiplin sebagai suatu sikap, perilaku dan perbuatan yang sesuai dengan peraturan dari perusahaan, baik tertulis maupun tidak tertulis.

Disiplin merupakan tindakan manajemen untuk mendorong para anggota organisasi memenuhi tuntutan berbagai ketentuan yang harus ditaati oleh karyawan. Pendisiplinan pegawai adalah suatu bentuk pelatihan yang berusaha memperbaiki dan membentuk 
pengetahuan, sikap dan perilaku karyawan sehingga para karyawan dapat bekerja secara kooperatif dengan karyawan yang lain serta meningkatkan prestasi kerjanya (Sondang P. Siagian, (2012:136). Dengan karyawan mematuhi peraturan yang telah ditetapkan oleh perusahaan dan mempunyai disiplin yang tinggi maka akan menciptakan suasana perusahaan lebih kondusif sehingga akan berdampak positif pada aktivitas perusahaan. Oleh karena itu, setiap perusahaan mempunyai harapan agar karyawan perusahaan dapat mematuhi peraturan yang telah ditetapkan.. 


\section{BAB II \\ MANAJEMEN SUMBER \\ DAYA MANUSIA}

\section{A. Manajemen}

\section{Pengertian Manajemen}

Manajemen berasal dari kata to manage yang berarti mengelola, menata, mengurus, mengatur, melaksanakan dan mengendalikan kegiatan organisasi dengan upaya anggota organisasi dan proses penggunaan semua sumber daya dalam organisasi untuk mencapai tujuan organisasi yang telah di tetapkan. Manajemen menurut Robbins dan Coulter (2014:7) mengemukakan bahwa manajemen adalah hal yang dilakukan oleh para manajer. Secara luas manajemen melibatkan aktivitas-aktivitas koordinasi dan pengawasan terhadap pekerjaan orang lain mencakup proses perencanaan, pengorganisasian, penggerakan dan pengendalian yang dilakukan untuk mencapai sasaran yang telah ditentukan melalui pemanfaatan sumber daya manusia dan sumber daya lainnya.

Handoko (2013:3) mengemukakan bahwa manajemen sebagai suatu cabang ilmu pengetahuan yang berusaha secara sistematis untuk memahami mengapa dan bagaimana manusia bekerja bersama untuk mencapai tujuan dan membuat sistem kerja sama ini lebih baik bermanfaat bagi manusia.

Dengan kata lain, manajemen menitik beratkan pada usaha memanfaatkan orang lain dalam 